\section{PMS 製凰による乳牛の卵胞囊腫 治療}

三宅 勝* 亀谷 勉* 佐々木敬功*

RoBERTs (1955) 1) は乳牛の卵胞囊腫治療飞 PMS 1, 000 2, 000 I.U. を使用しているが，治虑率 48\%で，よ い成績でなく囊腫破砕に勝る治療法であると述べている に過ぎない。しかるに西川ら(1957)2) が妊馬生血清拈よ び PMS 4, 500 15, 500 I.U. 27 例の乳牛卵胞囊腫治 療に使用したところ, 26例卯巣機能の回復を認めたと 報じてから, わが国家畜繁殖の分野に大きな反響が起 り，追試の必要が望まれてきたが， PMS 製剤は HCG 製剂に比較し高価であるためか追試の報告は少く, わず か飞熊谷ら (1958)3) が 2 例, 岸保 $\left.(1958)^{4}\right)$ が 4 例の乳牛 卵胞囊腫飞使用したという報告を行っているに過ざな い.な特最近は PMS 単独よりも PMS そ HCG の併 用がよいとする鹳守ら (1958)5) の報告がなされ, 従来の HCG 製剤一辺倒の卵胞囊腫治療に対していろいろ検討 が加光られるに至っている.

RoBERTs (1957)6) は卵胞囊腫治療当って, 最初用い た gonadotropin が無效であった場合は, 由来の異る他 のホルモンを用いるべきであると述べているが，私達る このような方法を必要とする症例に最近しばしば遭遇し ている.今回は昭和 32 年春以来, 囊腫の破砕, HCG の 反復注射など, 他のいかなる治療法によっても治癒の見 込久がなかった 5 例の乳牛卵胞囊腫に対して, PMS 製

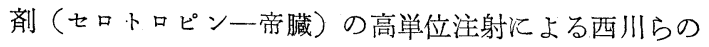
追試を行ったところ好結果を得たので，その試験概要を 報告卞る。

\section{試験材料並びに試験方法}

本試験は昭和 32 年 6 月より 33 年 9 月まで実施したもの で, 試験牛はいずれも十勝管内の農家に飼育されている ホルスタイン並びにホルスタイン系種の経産牛 5 頭で,

PMS 治療に至るまでの概況は第1表のようである.

すなおち試験牛は空胎期間中に飼羑管理の改善はもと より, 子宮洗滌, 囊腫の破碳, $\mathrm{HC} \mathrm{G}$ 製剤の反復投与など を実施したが，いずれも效果がなかったもので最終分婏 よりPMS 治療開始までに 165４30 日を要して拈り，

No.1, 3, 5 のごときは経過長期汸たるため廃用考慮中 のものであった. 症状は nymphomania 3 例, 発情不順 2 例で, この5ち 3 例に子宮疾患の併発が認められた.

以上の禀告並びに直晹検查などの所見から, 試験例は いずれも極めて慢性経過の, 治瘺困難な卵胞囊腫飞属す るものと考党られた。

PMS の注射は臨床診断後直ちに 1 回 8,000 I.U. (No.

\footnotetext{
* 帯広畜産大学
}

第 1 表 試験牛の概要

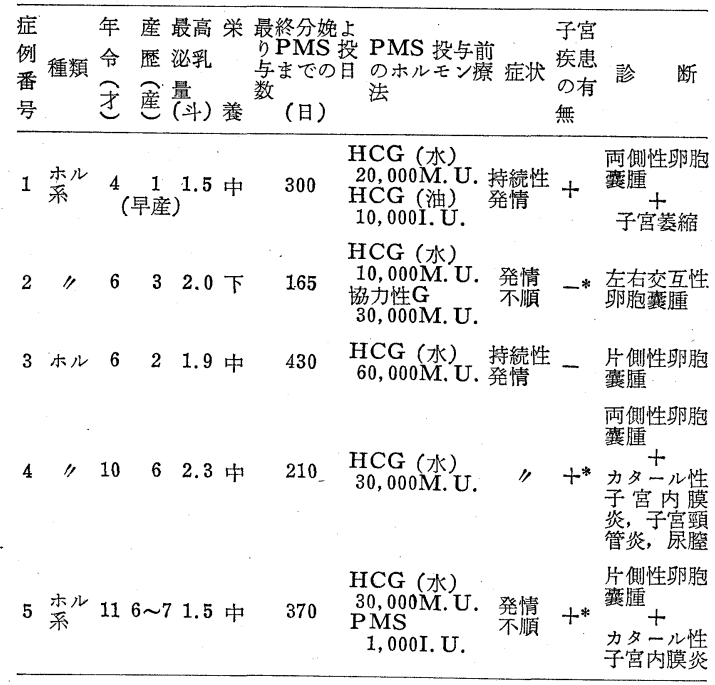

* 印は E.biopsy を実施したもの.

2 のみ 10,000 I.U.）を篎部筋肉内に注射した。なお No. 2 に対しては, PMS 第 1 回注射後 35 日目の検査に おいて,なんら卵巣機能の回復を見なかったので， 5,000 I.U.の追加注射を行的た。各例とも注射後飼養管理の 変換は一切畜主飞要求せず，また子宮疾患のあるもので も子宮洗滌は PMS 投与後卵栄機能回復を見るまでは一 時中止した. 注射後 $7 \sim 10$ 日毎に直晹検查を実施し, 卵 巣の変化を追求するとともに, 畜主には乳牛の挙動, 乳 量の変化などに十分注意するよう指示を与えた.

\section{試 験 成 樍}

その概要は第 2 表のようである.

第 2 表 試 験 成 績

\begin{tabular}{|c|c|c|c|c|c|c|c|c|c|c|c|c|}
\hline 症 & & & & & & 单の変化 & & & & & & 正常 結 \\
\hline 例 & & & & MS投与 & F前 & $\mathrm{PM}$ & AS投- & 与後 & 体化開 & & & 発情 \\
\hline 番 & & & & 栄容積 & & 卯栄最 & 率 & 所要 & $\begin{array}{l}\text { 姲业ひ } \\
\text { に完了 }\end{array}$ & 思特 & の減 & 回帰 \\
\hline 号 & 1 & $2 \mathrm{I} . \mathrm{T}$ & & $\mathrm{cc}$ & 数 & $\mathrm{Cc}$ & 数 & 日数 & 日数 & 数 & 少 & 日数 果 \\
\hline 1 & 8,000 & & & $\begin{array}{r}19.25 \\
135.00\end{array}$ & & & $\begin{array}{l}8 \\
6\end{array}$ & 9 & $7 \sim 30$ & 7 & - & 65 受 \\
\hline & 10,000 & 5,000 & 7 & $\begin{array}{l}51.30 \\
15.00\end{array}$ & $\begin{array}{l}3 \\
1\end{array}$ & $\begin{array}{l}29.12 \\
27.44\end{array}$ & $-\frac{-}{2}$ & $\overline{14}$ & $7 \sim$ & - & $1 / 2$ & 一 廃 \\
\hline 3 & 8,000 & & & $\begin{array}{r}36.75 \\
9.52\end{array}$ & 0 & $\begin{array}{l}157.50 \\
263.25\end{array}$ & $\begin{array}{c}5 \\
10>\end{array}$ & 26 & $16 \sim 35$ & 8 & - & 72 輷 \\
\hline 4 & 8,000 & & & $\begin{array}{l}72.00 \\
31.50\end{array}$ & $\begin{array}{l}3 \\
2\end{array}$ & $\begin{array}{r}336.00 \\
80.00\end{array}$ & $\begin{array}{l}5 \\
3\end{array}$ & 10 & $7 \sim 35$ & 10 & $1 / 3$ & 42 種付 \\
\hline 5 & 8,000 & & $v$ & $\begin{array}{l}36.00 \\
44.00\end{array}$ & $\begin{array}{l}0 \\
3\end{array}$ & $\begin{array}{r}44.00 \\
300.00\end{array}$ & $\left.\begin{array}{c}1 \\
10\end{array}\right\rangle$ & 14 & $14 \sim 35$ & - & - & 40 \\
\hline
\end{tabular}

PMS 注射後No. 2 以外の 4 例の卵栄には, 新生卵胞続 発のため, 西川らが述べているような著しい変化が起っ た.すなわち注射後 9〜26日目に数コ〜十数コの卵胞が 新生し, 卵巣容積は注射前の1.2〜28倍大に達した. PMS 注射前存在した囊胞はあるいは直ちに破裂し, あるいは 徐々に閉鎖黄体化したようであるが，多数の新生卵胞出 
現のためその確認は困難であった. No. 1，4,5の3例 は 7〜14日後から新生卵胞の黄体化が起ったため, この 時期を境に卵栄はその容積を減じたが，No. 3 のみは一 時縮小した卵巣が26日目に再び新たな卵胞の異常発育の ため卵巣容積は増大乙，右側は小児頭大となり最大值を 示した. 寸なわち本例は西川らのA型経過に類似し, No. 1, 4, 5 はB型経過をとったものと孝える.

しかるに無効の No. 2 にあっては, PMS 注射後 7 日 以内に既存の囊胞はすべて閉鎖黄体化したが, 新生卵胞 の発育はほとんどなかったため, 卵巣容積は健側がわず かに増大した程度で, 患側はむしろ注射前より縮小し た.この傾向は追加注射の場合も全く同様であった。

思牡狂症状の消失は PMS 注射後 7〜10日に起り, 卵 巣容積が最大に達した頃に一致していた，乳量の变化は 搾乳中の 2 例に減少が認められた. すなわち No.4 では 注射後 1 週間から $1 / 3$ に減じ, かつ乳はその後約 1 週間 凝固し, また無效の No. 2 では 1 週間目に $1 / 2$ に減じ た.

有効の 4 例は40〜72日目に正常発情の回帰があり, 直 腸検查の結果いずれも成熟卵胞が触知 (後日排卵確認) されたので, No.3, 5 は人工授精されたが, No.1, 4 は 子宮疾患があったため種付は延期された. その後の受胎 の有無については, No. 1 のみは第 2 回目の人工授精で 受胎し, 昭和33年10月雄犢を分婏したが, No. 4は目下第 2 回目の種付実施中で, また No. 3,5 は種付後第 1 回 目の発情予定日を待たずして転売されたため，妊否を確 かめ得なかった. しかしこの 2 例も完全に卵巣機能は回 復していたので有效例とした.

無効の No. 2 は第 2 回目の注射後約 3 力月目に rebound phenomen を期待し, 合成卵胞ホルモン（オイぶ スチン) 160 万I.U.の注射を行ったところ, 一時的な囊 胞の黄体化が起り, 卵巣は両側とも萎縮状態となった が， 2 週間後新たな囊胞の発生を認めたので，その後の 治療を中止した：本例はその後高度の趾間腐爛を併発し たため間もなく之殺された. 亡殺後の肉眼並びに顕微鏡 的所見では, 卵巣に小囊胞变性, 卵管に間質性炎, 子宮 に軽度のカタール性炎が認められた。

\section{考察}

乳牛の卵胞囊腫は, 山内ら (1954)7), (1953)8)の研究 により FSH 作用の過剩により起るから, その治療法と しては LH の補給, すなわら HCG 製剤の高単位注射 が最も效果のあることが明らかにされた。現在わが国で 実施されている治療法もほとんどこの方法で, 実際に極 めてよい成績があげられている.しかし多数の中には今 回の症例のごとく, HCG 製剤の反復注射によっても治 瘉せぬ場合がまれに起っている.この1つの原因として RoBERTs (1957)6)は antihormone が形成されるためで はないかと述べている. CoLE ら (1957)9) の実験による
と, 牛に最少生理的用量の gonadotropin (PMS) を用 いた際には antihormone の形成は起らなかったが，大 量(PMS 10,000 I.U. 1 週 1 回, 9１0 回) 用いた場合 には, 半数に antihormone の形成が認められたという ことである.HCG を用いたこのょうな実験は寡聞にし て知らないが, PMS 同様,蛋白製剤であるため, ある場 合には antihormone の生ずることが考兄られる・ホル モン剤は使用する製剤あるいは製品の相異とか, 注射さ れる個体の感受性の違いによって反応の現われ方が異る といわれているから, 個体によっては囊腫治療薬用量程 度の HCG 製剤でも antihormone の形成が懸念される わけである。

従って RoBerTs が述べているごとく, HCG の無效 な卵胞囊腫に対しては，性質の異る他のホルモン剤を用 いるのが合理的な治療法といらことになるが，性質の異 るという点では PMS む.APH あるいは progesterone などのごとく資格を有するわけである。

しかし PMS は衆知のごとく，FSH 作用は極めて強 いが LH 作用はほとんど認められないホルモン剤であ るため, これを FSH 作用の過剩である乳牛の卵胞囊腫 に対して使用することは，あたかも毒をもって毒を制す るような治療法で,一見無暴のように思われる.しかし 実際使用しての結果は西川, 熊谷らの成績のごとく, 今 回のわれわれの成績も極めて満足すべきもので, 臨床的 応用価値の高いことがわかった.

しからばいかなる作用機序で PMS は乳牛の卵胞囊腫 に有效であるのかといらことになるが，われわれはこれ を説明するだけの十分な知識を持ち合せていないしま た誰も明確な解答は下していない. 動物の性活動, とく に卵巣機能を支配する各種ホルモンの動きは, 今日知ら れている以上に複雑, 微妙なものがあり, gonadotropin についても, FSH と LH. LTHの相互関係とか他のホ ルモンとの関係などについてまだまだ未知な点が多いた め, 乳牛卵胞囊腫の PMS による治療に対しても合理的 な解釈をつけることは不可能と思う。

今回実施した試験の成績を西川ら，あるいは熊谷らの 成績と比較してみると，(1)注射後卵巣に起った変化はほ とえぞ前二者にひとしく，9～26日目に最大に達し,(2)思 牡狂の消失はやや早く 7 10日目で, (3)乳量は西川らの ごとく, 泌乳中の 2 例はいずれも減少が見られ, 熊谷ら のごとく増加したものはなかった. (4)正常発情の回㛿は 西川らの 3，40日に比較するとやや遅く $40 \sim 72$ 日を要し た. (5)最も興味深いのは子宮の変化で，PMS 投与前 No. 1 は子宮壁は著しく菲薄, 弛緩高度で, 無力状態に あり, No. 3 は子宮弛緩下垂, 高度の子宮頸の哆開, 尿 胵などがあり，No. 5 は著しい子宮壁の肥厚が認められ た例で, 後二者は Endometrial-Biopsy により慢性カ タール性子宮内膜炎と訬断された。しかるに PMS 注射 後卵巣機能回復とともに, 子宮は収縮性を増加し, 子宮

日獣会誌 12 (1959) 
壁は厚さが正常となり，触診飞当って弾力性を感ずるな ぞ，その回復は蹎著なものがあった．しかしいずれも極 めて慢性経過の子宮内膜炎であったため, 卵巣機能回復 後子宮が正常化するまでには, No.1 では 3 カ月, No.4 では 2 カ月間（この間子宮洗滌 $1 \sim 2$ 回）を要した。

\section{結言}

慢性経過の乳牛卵胞囊腫 $\mathbf{5}$ 例に PMS(セロトロピン) 8, 000 10, 000 I.U. の 1 回注射を行ったところ，4 例に 卵巣機能の回復を認めた。 とくに本治療法は HCG 製剤 を反復使用しても，無効の乳牛卵胞囊腫汇対して効果的 であることを述べた。

本試験を終るに当り御協力をいただいた大正，清水， 川西農共家畜診療所の各位, 病理組織標本の御指導をい ただいた本学上田教授並びにセロトロピンを供試して下 さった帝国藏器製薬株式会社汇深謝する。

\section{参考文献}

1) ROBERTS, S.J. : Cornell Vet. 45, 497 (1955). 2) 西川 (義), 杉江(佶): 家繁侀誌，3，27 (1957)。 3) 熊谷(泰), 守屋(雅), 柏 植(克), 田中(義): 北獣会誌, 2, 8 (1958).4) 岸保(芳): 家繁研誌, 4, 17 (1958)，5）萄守(奄), 高橋 (正): 同誌, 4, 8 (1958). 6) ROBERTS, S.J. : Vet. Rec. 69, 667 (1957). 7) 山内(亮), 芦 田(浄), 乾(純): 日獣学誌, 16,65 (1954)。 8) 山内(亮)：日獣会誌, 6, 351 (1953). 9) COLE, H.H.C. HAMBURGER \& A.NEIMAN-SORENSEN : Acta, Endoc. 26, 286 (1957). (Summary. Vet. Bull. 28, 159, 1958).

\section{犬の外聴道炎臨床集}

米 倉 忠 夫*

小動物臨床部門に抒いて，とくに外聴道炎は治癒率の 悪い疾病に考兄られる。字た慢性化した患犬に至っては， ただ単なる外聴道の消毒，清潔，抗生物質の応用の文で は治瘾に至る場合が少なく，とく泟性の場合は数年以 上る経過して十指にあまる獣医師に治療経験を有する患 畜も，2〜3筆者らは診察，加療を試みたことが出る. とく慢性化した患犬で外聴道内面表皮の肥厚して内面 各突起が相互に接触をきたして潰瘍面をつくり, 渗出液 を分泌し，内部よりのバタ一状の分泌物と混合し，一種 独特の悪臭を発するようになると，普通一般の治潦法で はとても治瘉しないことは臨木獣医師は皆一様に体験し ているところと思われる。

すでに本疾病に対して臨床方面の各氏がその治療法招 よび使用薬について発表されているが，筆者の追試の方 法が不完全かも知れなかったが，あまりよい成績を示さ なかった．現在までの大要は抗生物質的な傾向を有する 薬品の使用が，とくに多く使用されているのではなから

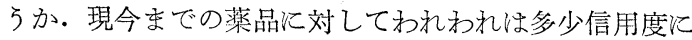
ついて再検討する必要があるのではないだろらか。

筆者はさきに慢性化した外聴道炎患犬に対して外科的
療法を加觉て好成績を収めたことを発表したが，本例の 場合は慢性化した患犬に外科的手技を応用して十分なる 成績を得ることができる. しかし，一方急性の場合の治 療法となると，その治療法が区々であって，各人独自の 方法を用いているょうである，各個人の技術が十分なる 場合は必ず完治するから慢性化することを防止できる が，必ずしもそうでないこと沉って慢性化現象が起っ てくるわけである.

今回はとくに急性症状をきたした患犬を主として，時 飞慢性化した患犬も外科的手技を併用して治療試験を行 ってみたので，ここに報告する。

試薬 Oticole (オチュール)（三昭製薬kk）

主剤扔よび配合薬内容はつぎの通りである.

Silver Oxide
Glycerinum
Polyethihlu Glycol
Aethylis Paraoxybenzoas
Butylis Paraoxybenzoas
Silver Protein
Sodii Laurylis Sulfas
Propylen Glycol
Aqua Destial

\section{使 用 法}

本剤はチューブ入りであるために，外聴道深部にまで 容易汇注入することが可能である. 1 回の使用量は 0.3 $\sim 0.8 \mathrm{cc}$ 位を 1 回の注入量として用いる場合が好結果を きたす。な拉，本剤使用前汇綿棒で患部を $3 \sim 4$ 度清潔 にして赫いてから本剤を注入し, 後に外部発毛部より示 指拈よび拇指頭にてょく内部拊着するようにマッサー ジをすることが必要であると同時に，油性のペニシリン を併用することも重要である。

\section{成績}

本試験は昭和33年 4 ～12月までの成績である.

Oticole 塸床成績 表

\begin{tabular}{|c|c|c|c|c|c|c|c|c|}
\hline & 類 & 性 & $\begin{array}{l}\text { 年 } \\
\text { 令 }\end{array}$ & $\begin{array}{l}\text { 病 } \\
\text { 勢 }\end{array}$ & $\begin{array}{l}\text { 発病後 } \\
\text { 数 }\end{array}$ & $\begin{array}{l}\text { 治電 } \\
\text { 数 }\end{array}$ & 要 & 転淵 \\
\hline 1 & 雑 & 우 & 4 & H & 3 力月 & 6 & ペニシリン併用 & 治 \\
\hline 2 & シェパード & 今ิ & 2 & H & $1 "$ & 8 & " & " \\
\hline 3 & プードル & 우 & 1 & + & $1 "$ & 4 & " & " \\
\hline 4 & 秋田 & 今 & 2 & \# & $1 " \prime$ & 6 & ", ブリサイ併用 & " \\
\hline 5 & 雑 & " & 3 & $H$ & 20 日 & 4 & ペニシリン併用 & " \\
\hline 6 & 柴 & " & 1 & H & 1 力月 & 4 & " & " \\
\hline 7 & シェパード & " & 3 & \# & $2 " 1$ & 7 & ", ストマイ併用 & " \\
\hline 8 & $=y-$ & 우 & 1 & + & 20 日 & 3 & ペニシリン併用 & " \\
\hline 9 & シェパード & $\hat{o}$ & 4 & W & 4 力月 & 14 & V字状切開, ペ併用 & " \\
\hline 10 & スピッッ & " & 1 & \# & 20 日 & 4 & ペニシリン併用 & " \\
\hline 11 & " & 우 & 6 & H & 11カ月 & 21 回 & $\mathrm{V}$ 字状切開, ぺ併用 & " \\
\hline 12 & シェパード & 今 & 2 & \# & $1 / 1$ & 5 & ペニシリン併用 & " \\
\hline 13 & スピッッ & 우 & 6力月 & 月井 & 10 日 & 4 & " & " \\
\hline 14 & 雑種 & 今 & 2 & \# & 2 力月 & 6 & " & " \\
\hline 15 & スパニール & " & 4 & 曲 & $2 " 1$ & 9 & " & " \\
\hline 16 & 雑種 & 우 & 2 & \# & $2 " \prime$ & 8 & " & " \\
\hline 17 & スパニール & $\hat{0}$ & 1 & WH & 15 日 & 11 & " & " \\
\hline
\end{tabular}

